\title{
Gap Fraction Estimates over Selectively Logged Forests in Western Amazon
}

\author{
Ekena Rangel Pinagé1,2, Eraldo A. T. Matricardi', Liliana Sayuri Osako², \\ Alessandra Rodrigues Gomes ${ }^{3}$ \\ ${ }^{1}$ Department of Forestry, University of Brasília, Brasília, Brazil \\ ${ }^{2}$ Brazilian Forest Service, Brasília, Brazil \\ ${ }^{3}$ Centro Regional da Amazônia, National Institute for Space Research, Belém, Brazil \\ Email: ekenapinge@hotmail.com
}

Received 19 September 2014; revised 30 October 2014; accepted 12 November 2014

Copyright (C) 2014 by authors and Scientific Research Publishing Inc.

This work is licensed under the Creative Commons Attribution International License (CC BY).

http://creativecommons.org/licenses/by/4.0/

(c) (i) Open Access

\begin{abstract}
Gap fraction is a biophysical variable related to energy balance, forest fauna, micro-climate and regeneration, and is an important indicator of forest management quality. The objective of this study was to compare gap fraction estimates from undisturbed forests and different environments or strata of selectively logged areas. Moreover, gap fraction measurements were collected with two distinct instruments (optical canopy analyzer LAI-2000 and hemispherical photographs). Field data were collected from two sustainable forest management sites at Jamari National Forest, Rondônia State, Brazilian Amazon. Our results indicated significant differences between data acquired using these two instruments. For instance, the LAI-2000 data showed greater variation for each environment compared to hemispherical photographics data, and the data were also more sensitive to the increase in gap fraction. Small variations were found in the gap fraction means for the two study areas, and only data for the undisturbed area were significantly different. A gradient of increasing gap fraction that ranged from primary forests to log decks was observed. Furthermore, a multiple linear regression analysis determined the contribution of the selectively logged environments to decreased forest cover, confirming the observed gradient.
\end{abstract}

\section{Keywords}

Gap Fraction, Sustainable Forest Management, Canopy Analyzer

\section{Introduction}

Severe damage to the remaining forest is caused by conventional logging and by not applying forest manage- 
ment techniques. The most scathing damages result from the displacement of logging machines during the opening of roads as well as skid trails and logs that are dragged from the forest to the log decks. Additional damage is caused when trees are felled. Moreover, the fall of a single tree creates gaps when there are lianas linking its treetop to other trees, or when it falls over and kills the smaller trees ones that could be harvested in the future. According to Johns et al. [1], for each tree harvested 27 other with diameter at breast height (dbh) greater than $10 \mathrm{~cm}$ are damaged during conventional logging in the uplands. These combined damages cause forest canopy openness that is approximately $50 \%$ greater than that caused by sustainable forest management [2].

Gap fraction is defined as the fraction of sky visible through the canopy [3]. In areas under selective logging, it is maximized by the selective extraction of individual trees and the opening of infrastructure for timber activities. Furthermore, gap fraction is considered as an important impact indicator of forest management, since it is directly related to important ecological processes such as energy balance, development of forest fauna, microclimate, and regeneration, among others [4].

Changes to the canopy caused by logging activities affect forest regeneration and can impact the genetic diversity and demographic structure of species as well as the diversity and abundance of forest fauna [5]-[7]. Moreover, the higher amount of incident radiation on the understory increases the susceptibility of the forest to fires, due to modification of the micro-climate and an increase in the amount of fuel material [8] [9].

Several optical techniques are commonly used as indirect methods to derive Leaf Area Index (LAI) and gap fraction data, including LICOR LAI-2000 and hemispherical photography using fisheye lens. Optical techniques are based on measurements of light transmittance through the canopy [10] [11]. Various articles have discussed and compared the data retrieved from different methods [10]-[13], indicating key biophysical parameters and instrument settings for different canopy structures. Overall, the literature suggests that consistency between these retrieval techniques varies with vegetation type, range of retrieved LAI, selection of retrieval parameters, and illumination conditions [14]-[17].

LAI-2000 equipment is usually used to measure LAI, but it was used to collect gap fraction data in this study, which is the basic measurement of the instrument [3]. LAI is a quantitative measurement derived from canopy openness combined with a leaf distribution model. However, gap fraction is a more significant measurement than LAI in spatially structured and highly discontinuous forest cover conditions [4], as is the case in our study area.

Hemispherical photography consists of techniques for the study of plant canopies through photos acquired with a hemispheric (fisheye) lens under the canopy (oriented to the zenith) or positioned above the canopy (oriented to the ground). Hemispherical photography provides a permanent record of the data collected containing valuable information about the position, size, density and distribution of the canopy. In general, the hemispheric photographs provide an extreme view angle (generally $180^{\circ}$ ), and produce a projection of the hemisphere on a plain surface [10] [18].

The goal of this research was to compare gap fraction estimates from undisturbed forests and different environments or strata of selectively logged areas as well as gap fraction measurements collected with two distinct instruments (LAI-2000 canopy analyzer and hemispheric photographs). On this regard, we aimed to improve the existing analytical tools being used to estimate the impacts of selective logging on forest canopy.

Our study area was the forest concession at Jamari National Forest (JNF), located in Rondônia State, western Amazonia. The different environments of the analyzed logged regions included areas of primary or undisturbed forest and those generated by logging activities in a forest management area (e.g. tree fall gaps, skid trails, log decks, and primary and secondary roads).

\section{Materials and Methods}

\subsection{Study Area}

According to the Brazilian National System of Protected Areas (SNUC), the primary objective of the National Forest category is ensuring the multiple sustainable use of forest resources and scientific research, with an emphasis on methods for the sustainable use of native forests [19]. JNF is a Sustainable Use Protected Area, established 1984. It is located in the municipalities of Itapuã do Oeste, Cujubim and Candeias do Jamari, state of Rondônia, western Amazonia, and it encompasses an area of 220,000 ha (Figure 1).

JNF mostly includes dense tropical forests with areas of open tropical forests [20]. This vegetation type is characterized by the richness of spaced individual trees, which eventually exhibit clusters of palm trees and 
richness of woody lianas and epiphytes. The understory is predominantly composed of seedlings and saplings from species of taller trees.

In 2008 an area of 96,000 ha at JNF was allocated for forest concession, and it was parceled into three management units, which constituted the first area under this type of allowance in Brazil.

Our study sites were the first Annual Forest Production Plots Units (AFPP) of Forest Management Units (FMU) 1 and 2 of JNF (see yellow outlined polygons in Figure 1). The areas in the FMU 1 and FMU 2 covers 594 ha and $1068 \mathrm{ha}$, respectively. The average logging intensities were $14.8 \mathrm{~m}^{3} \cdot \mathrm{ha}^{-1}$ and $9.6 \mathrm{~m}^{3} \cdot \mathrm{ha}^{-1}$, respectively.

\subsection{Fieldwork}

Fieldwork was conducted in October 3-15, 2011 and involved the gap fraction acquisition data in different forest environments caused by logging activities, including forest gaps from felled trees, skid trails, log decks, and primary and secondary roads. Similarly, gap fraction data were acquired within undisturbed forests that were used as control areas. Studies that applied similar approach to collect gap fraction data include [4] [21] [22].

The sampling scheme designed for the fieldwork (acquisition of gap fraction data) in the different selective logging environments included the following steps: 1) All log decks in the two study areas were measured; 2) All patches of primary and secondary roads in each AFPP were measured, in one randomly selected $100 \mathrm{~m}$ or two $50 \mathrm{~m}$ transects. Measurements were taken at each $10 \mathrm{~m}$-interval; 3) Skid trails were measured within $50 \mathrm{~m}$ transects, and where selected to avoid tree gaps and log decks. The number of trails patches measured equaled the number of road patches in each study area; 4) For measurements of tree fall gaps, trees were randomly selected in the field, in the same amount as the road patches. Transects began at the tree stump, and continued for $50 \mathrm{~m}$ in the direction of the tree fall. Measurements were taken at each $10 \mathrm{~m}$-interval; 5) Within undisturbed areas, one $1000 \mathrm{~m}$ or two $500 \mathrm{~m}$ transects were sampled and measurements were taken at each $20 \mathrm{~m}$ intervals. Areas to be harvested in subsequent years were considered undisturbed areas.

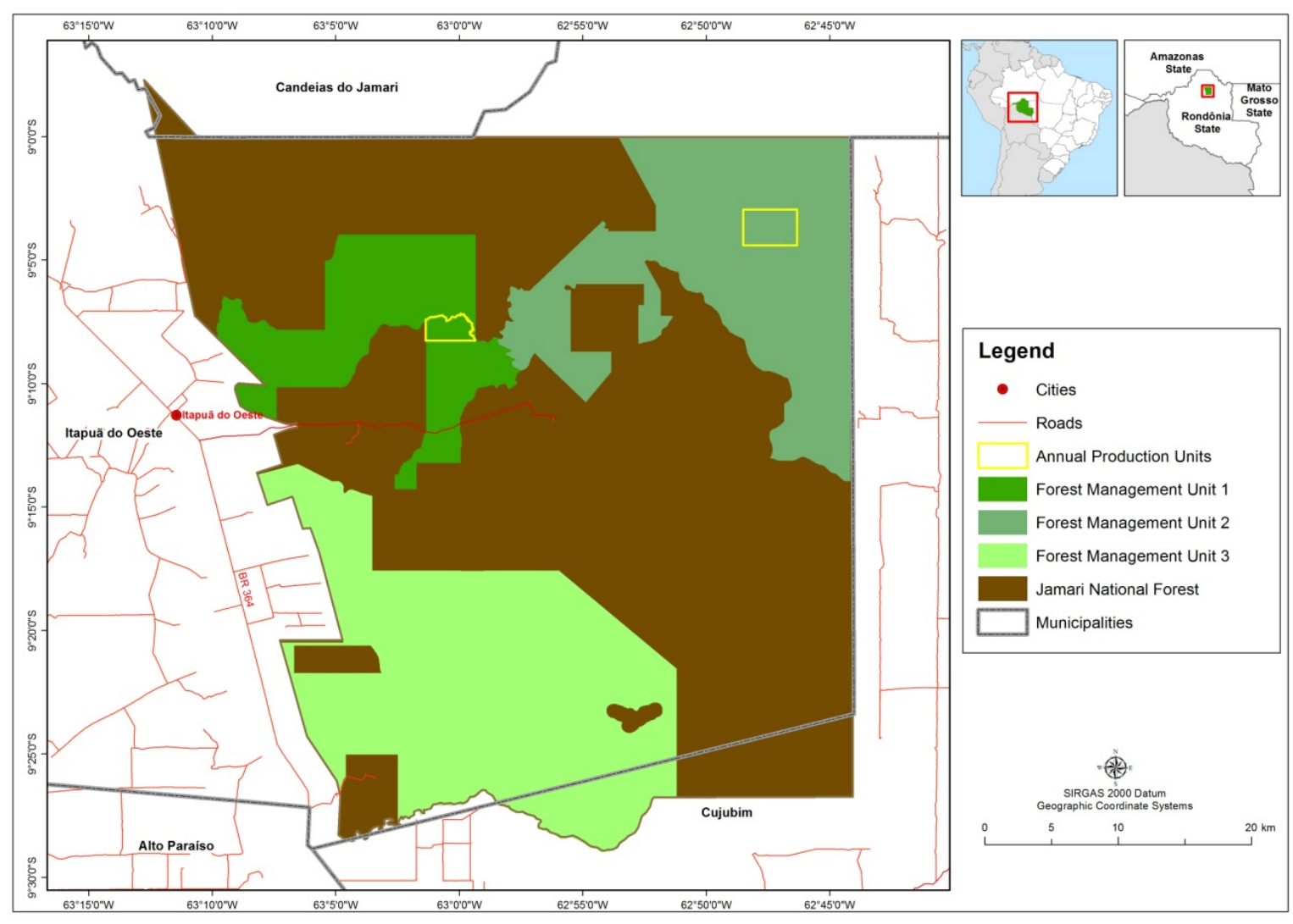

Figure 1. Location of Jamari National Forest (JNF), its Forest Management Units, and the Annual Forest Production Units, our study areas. 


\subsection{Instruments Used in Fieldwork}

In the field, two distinct devices were used to collect light levels below the canopy. The first one was the LAI2000 plant canopy analyzer, and the second utilized a fisheye lens attached to a digital camera.

The LAI-2000 device uses a nondestructive method to calculate the LAI and other structural attributes of various types of vegetation cover. The radiation measurements are performed by an optical fisheye sensor with a $148^{\circ}$ field of view. The light interception by the forest cover is estimated by measurements below the canopy that were taken at in five different angles (Figure 2).

The optical sensor detector is characterized by five silicon detectors arranged in concentric rings, which calculates the intercept of blue light in the spectral range of $320-490 \mathrm{~nm}$. Thus, when radiation is projected onto the detectors, each is sensitized at a different angle. The filter causes the foliage to look "black" against the lighter sky. The output of each detector ring is proportional to the fraction of the sky-illuminated ring (or residual scattered radiation) [23].

The LAI-2000 unit is equipped with two sensors, which were arranged in the field as follows: one was kept in an open area under ambient lighting conditions and took measurements of diffuse lighting every 15 seconds, while the other sensor was carried inside the forest, and measurements were taken at each point, as described in Section 2.2.

In addition to the measurements taken with the LAI-2000 sensor, at each field point it was also acquired a hemispherical photo with a 3.2 megapixel camera coupled with a fisheye lens and a vertical-horizontal leveler.

Measurements were taken simultaneously with both instruments under favorable weather conditions (no rain) and during the daytime to avoid incidence of direct solar radiation (from 6:30 to 8:30 am and 3:30 to 5:00 pm). All sampling points were georeferenced with a navigation GPS receiver.

\subsection{Processing of Field Data}

Data collected with the LAI-2000 instrument were stored in the memory of the devices. The data were subsequently processed with the FV-2000 software, which combines the tables from the two sensors and generates the percentage of canopy cover, among other biophysical parameters. Data from the outermost ring $\left(61^{\circ}-74^{\circ}\right)$, were excluded from the analyses in order to avoid forest edges in the clearings during open sky calibration measurements, as recommended by LICOR protocol [23].

Measurements of gap fraction for each collected hemispheric photo were calculated using Gap Light Analyzer (GLA) software [24], which provides a semi-automatic technique for calculation, because each photo requires a threshold for the determination of canopy openness that is empirically defined by the interpreter. In general, we used the standard threshold applied by GLA (128), but in some photos, the threshold was adjusted based on sun exposure. After this step, a binary image was generated for each photo, and percentages of canopy cover were computed from these images (Figure 3).

Table 1 describes the amount of valid points acquired in each strata in the two study areas. Only points with valid measures in both instruments after field data processing were considered. For illustrating purposes, Figure 4 shows an example of both a hemispherical and a ground photo of each selective logging environment.

\subsection{Data Analysis}

The Pearson correlation coefficient was used to determine the degree of correlation between the data collected with both devices from the different logging environments. The Student's $t$ test $(\alpha=0.05)$ was applied to determine if the mean gap fraction values in the logged areas environments were significantly different from the mean values found in undisturbed forest areas. The $t$-test $(\alpha=0.05)$ was also used to determine if there was a

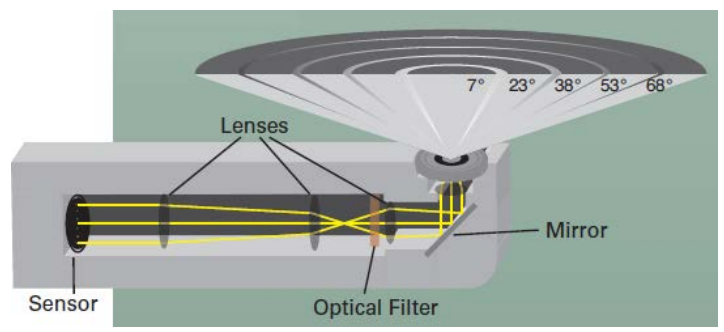

Figure 2. LAI-2000 sensor [23]. 


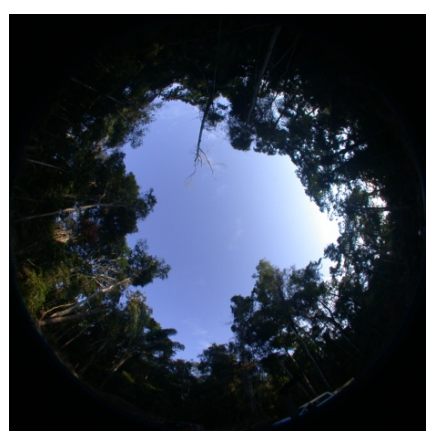

(a)

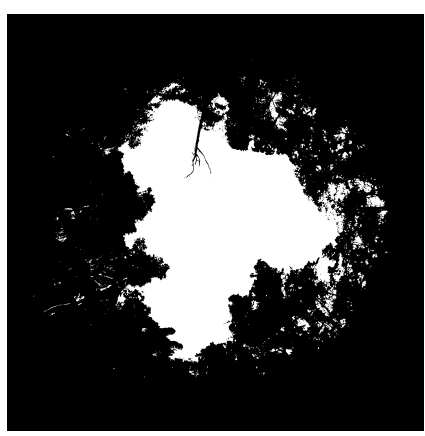

(b)

Figure 3. Example of (a) hemispherical photograph of a log deck and (b) binary image resulting from GLA the processing.

Table 1. Number of valid points for each environment from both study areas.

\begin{tabular}{cccc}
\hline Environments & Study area 1 & Study area 2 & Total \\
\hline Undisturbed forest & 119 & 50 & 169 \\
Skid trails & 45 & 36 & 81 \\
Secondary roads & 66 & 214 & 280 \\
Tree fall gaps & 88 & 52 & 140 \\
Primary roads & 22 & 38 & 60 \\
Log decks & 44 & 55 & 99 \\
Total & 384 & 445 & 829 \\
\hline
\end{tabular}
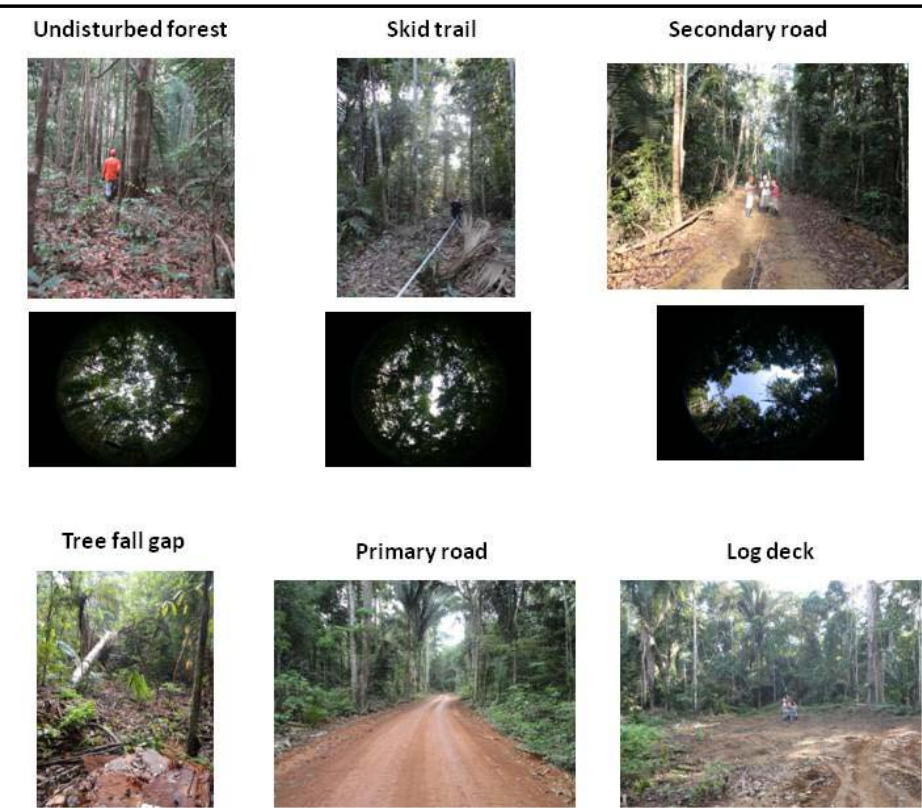

Primary road

Log deck
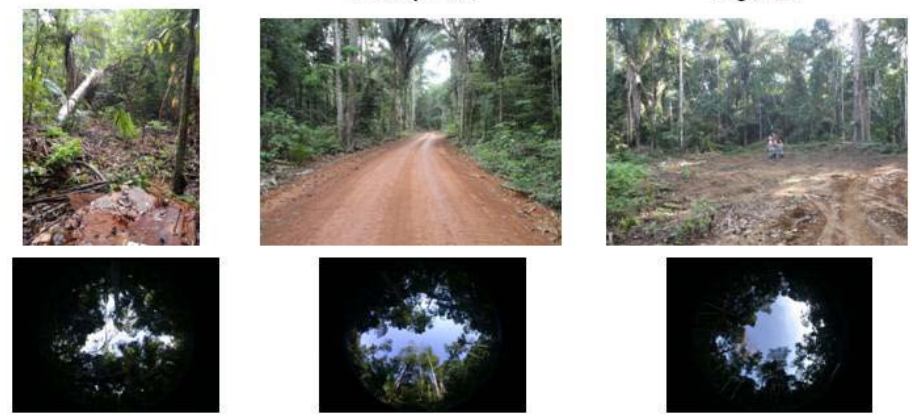

Figure 4. Examples of ground and hemispherical photographs of the five logging environments and undisturbed forest. 
significant difference between gap fractions of different environments from the two study areas.

Finally, multiple linear regression techniques were applied to determine the contribution of each logging environment to forest cover. The proportion of forest cover adopted in this study was defined as the reverse of gap fraction or canopy opening (calculated as 100\%-percentage of gap fraction at each point). Total forest cover was considered a dependent variable and the forest cover in each of the five logged area environments were considered as independent variables. The multiple linear regression $(\alpha=0.05)$ model for the tested dependent variable was defined as:

$$
\mathrm{DV}=\beta 0+\beta 1 \mathrm{X} 1+\beta 2 \mathrm{X} 2+\beta 3 \mathrm{X} 3+\beta 4 \mathrm{X} 4+\beta 5 \mathrm{X} 5+\mu
$$

where DV is the dependent variable (forest cover), $\beta 0$ is the constant or intercept of the $\mathrm{Y}$ axis, $\beta 1$ is the coefficient associated with the independent variable $\mathrm{X} 1$ (log decks), $\beta 2$ is the coefficient associated with the independent variable $\mathrm{X} 2$ (primary roads), $\beta 3$ is the coefficient associated with the independent variable $\mathrm{X} 3$ (roads secondary), $\beta 4$ is the coefficient associated with the independent variable $\mathrm{X} 4$ (tree fall gaps) and $\beta 5$ is the coefficient associated with the independent variable X5 (skid trails). The variable $\mu$ is the associated error, which includes factors other than the independent variables considered in this model.

Table 2 shows the null hypothesis defined for each independent variable that were considered in the regression model.

\section{Results and Discussions}

Gap fraction data retrieved from both methods produced information that was quite distinct. The mean and standard deviation values of gap fraction for each environment are shown in Figure 5. The largest relative difference occurred in the undisturbed forest class, and the LAI-2000 percentage cover of $3.5 \%$ was comparable to that found by [4]. However, the hemispherical photographs rate of $10.6 \%$ was similar to that reported by [25] for a dense forest in the Amazon biome.

For measurements collected in the logged areas, LAI-2000 showed higher means than the hemispherical photographs. Furthermore, as the gap fraction of the strata increases, the difference between the two methods becomes larger. These results suggest that LAI-2000 data are more prone to overestimations of gap fraction in those situations. Garrigues et al. [17] found that the sensitivity of the hemispherical photography method to illumination conditions is low (14\% compared to $28 \%$ of LAI-2000), and also reported that LAI-2000 gap fraction measurements for crop canopies are more variable than those obtained with the photos.

Table 3 presents the Pearson correlation coefficients between the measurements obtained with both instruments for each analyzed environment. The undisturbed forest class has the lowest correlation between the measurements. The large number of contact points between sky and canopy vegetation present in this environment may explain this difference because this aspect is handled differently by the two data processing: the LAI-2000 assumes that the foliage is a black body that absorbs all received light. However, the vegetation pixels in the hemispherical photos that are located at the borders of gaps are very bright and during processing can be classified as sky pixels, especially in pictures with high sun exposure.

Among the logged area environments, data obtained at tree fall gaps showed more consistency between the two methods, and those obtained in skid trails showed the lowest correlation. Importantly, despite having the lowest correlation coefficient, skid trails exhibited the lowest mean difference between the two instruments (Table 3).

Regarding the comparison between different strata and between the two areas under forest concession (AFPP 1 of FMU 1 and 2), only measurements with hemispherical photographs were used, because they were found to be more consistent (lower standard deviation and lower sensitivity to increased light penetration in the canopy).

Table 2. Description of the null hypothesis.

\begin{tabular}{cc}
\hline Hypothesis for the coefficient & Hypothesis description \\
\hline$\beta 1=0$ & Log decks have no influence on forest cover \\
$\beta 2=0$ & Primary roads have no influence on forest cover \\
$\beta 3=0$ & Secondary roads have no influence on forest cover \\
$\beta 4=0$ & Tree fall gaps have no influence on forest cover \\
$\beta 5=0$ & Skid trails have no influence on forest cover \\
\hline
\end{tabular}




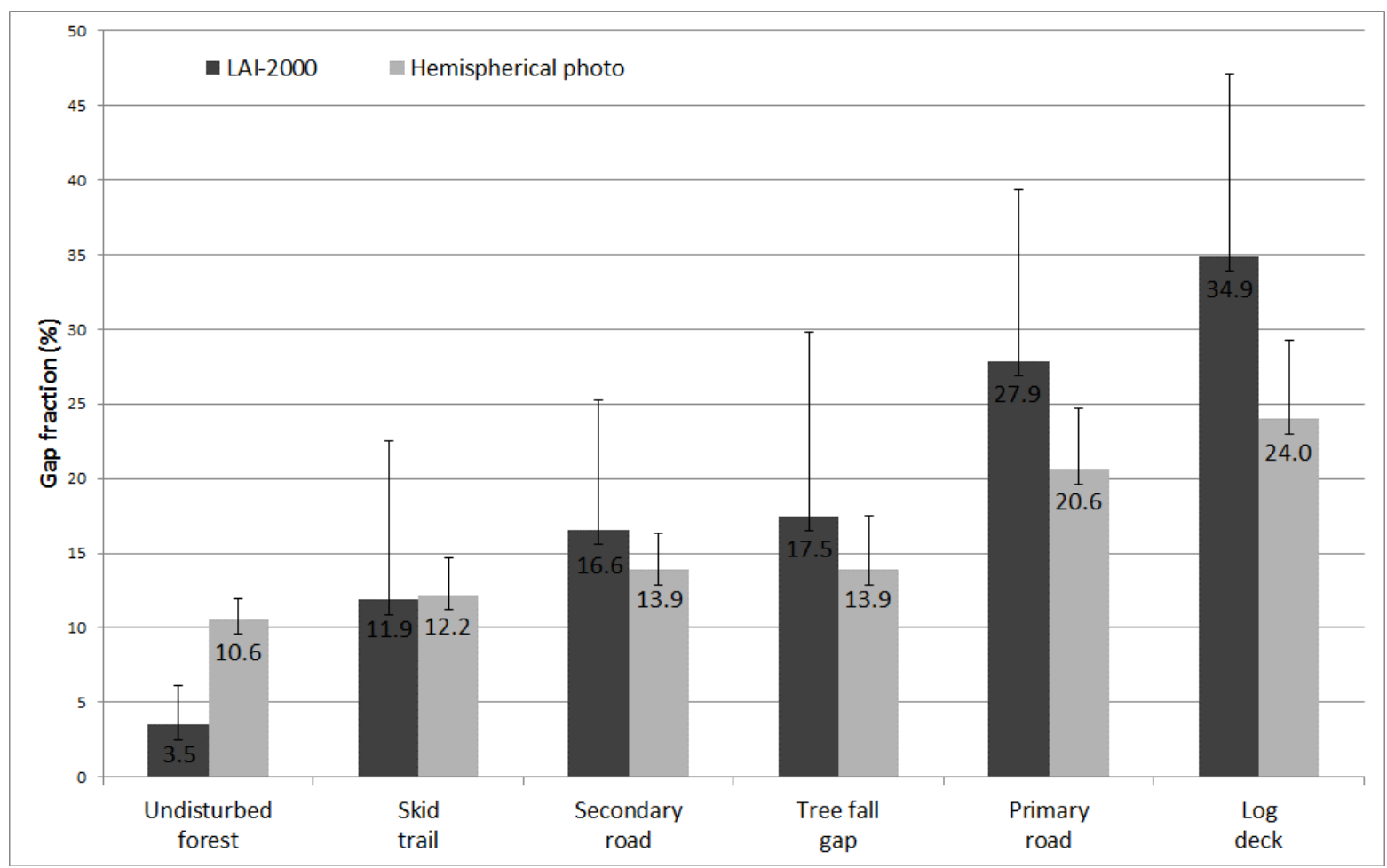

Figure 5. Gap fraction mean and standard deviation of the six analyzed environments that were computed using both methods.

Table 3. Pearson correlation coefficient between measures obtained from both instruments for each analyzed environment.

\begin{tabular}{cc}
\hline Study area environment & Correlation coefficient \\
\hline Undisturbed forest & 0.14 \\
Skid trail & 0.58 \\
Secondary road & 0.63 \\
Tree fall gap & 0.83 \\
Primary road & 0.71 \\
Log deck & 0.61 \\
\hline
\end{tabular}

Furthermore, visual inspection of photographs suggests that the results generated by this instrument are more consistent (Figure 6).

The results illustrated in Figure 7 reveal that there was little variation in gap fraction between the two study sites. Only the undisturbed forest class showed a significant difference between treatments (calculated $t=4.9683$, critical $t=1.6540$ ). Regarding the strata of the logged areas, only primary roads showed a difference of more than $1 \%$, but this was not statistically significant (calculated $t=-1.5014$, critical $t=1.6540$ ). These results suggest that there was no significant difference in the impact on the forest canopy caused by the two companies holding the forest concession contract. However, our results indicate that sustainable forest management executed by the company holding FMU 1 is more efficient, given that it produced a greater logging volume with a similar impact on the forest.

Sustainable forest management causes different levels of canopy openness in the strata. For instance, there are those that require the total removal of vegetation cover and soil exposure, such as log decks and primary roads, (the main evidence of detectable using selective logging detectable in medium spatial resolution satellite imagery). However, there are still those strata that cause fewer disturbances in the canopy, with most of the impact occurring at the ground and understory levels, including secondary roads and skid trails. Tree fall gaps usually 


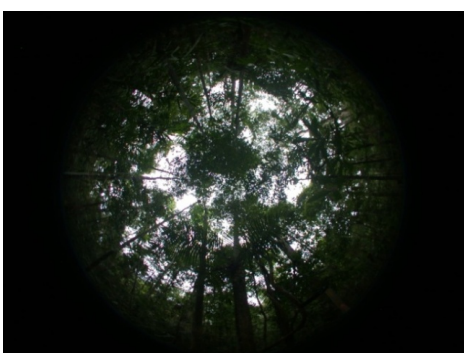

(a) 11.07 (1) and 1.50 (2)

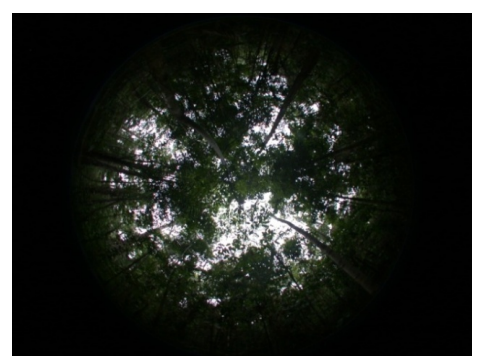

(b) 8.93 (1) and 2.3 (2)

Figure 6. Hemispherical photos of undisturbed forests in study area 1 (a) and study area 2 (b). Values indicate gap fraction percentage obtained from hemispherical photos (1) and from LAI2000 (2).

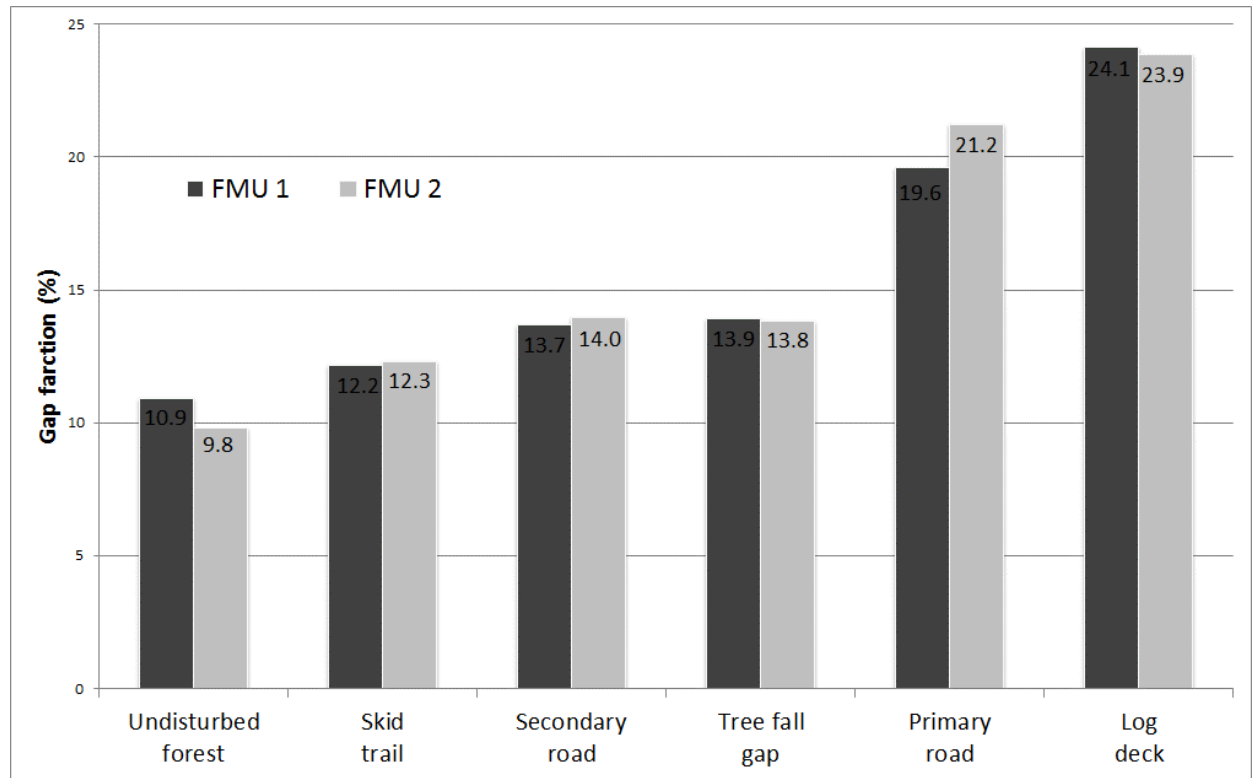

Figure 7. Gap fraction in different analyzed strata from both study areas based on from hemispherical photos.

leave non photosynthetic dry vegetation on the ground along with moderate canopy openness, and after a given period, the forest canopy returns to its original state.

The results presented in Figure 6 show that the skid trail was the strata that caused the least amount of canopy opening, with a maximum variation of $2.5 \%$ compared to the undisturbed forests. When a skid trail is opened, large trees that could cause large gaps in the canopy are not felled, and only trails that are $3-4 \mathrm{~m}$ wide are opened on the ground to allow the transit of skidder machinery.

Secondary roads and tree fall gaps have an equivalent percentage of gap fraction, that is $3 \%$ - $4 \%$ higher than undisturbed forests, because the opening of these strata may fell down larger trees. In the case of roads, opening may even bare portions of soil, but they are only designed for short periods of traffic during logging operations in that area. A forest canopy starts to close in less than a year.

Primary roads increased canopy openness by about $10 \%$ compared to undisturbed areas. These features undergo permanent traffic, which requires an approximately $6 \mathrm{~m}$ wide roadbed opening plus $2 \mathrm{~m}$ on each side, as well as periodic maintenance to prevent forest regeneration and erosion. In general, sectors other than the forest concession also use these roads, which are distinguishable even when using medium spatial resolution satellite imagery.

Finally, the highest percentage of gap fraction occurs in the log decks, and the means are about $15 \%$ higher than that of undisturbed forests. These elements of the logged forests have an area of $500 \mathrm{~m}^{2}$, and they exhibit higher canopy opening detectable in the hemispheric photo because of their circular shape. For example, the 
secondary roads are linear structures, and although they represent a larger area in the AFPP, they exhibit lower gap fraction at a specific point.

The existing gradient between the strata of the logged areas was also substantiated after the application of multiple linear regression analysis using the estimated forest cover from hemispherical photographs as the dependent variable. Table 4 presents the coefficient of determination and standard errors relative to the model, and Table 5 shows the adjusted coefficients for each independent variable.

Once forest cover is presented as a percentage, the coefficients of the variables are quite explicit, translating their negative contribution to forest cover when compared to an undisturbed forest cover, described by the constant of the model.

The estimated coefficients for each stratum were as follows: -13.95 for log decks; -10.76 for primary roads; -3.40 for secondary roads; -3.78 for tree fall gaps and -1.48 for skid trails. All coefficients were significant at a confidence level of $95 \%$. Thus, we can reject the null hypothesis for all strata, and can assume that all strata influence the estimated forest cover at the ground level.

The adjusted model coefficient of determination was 0.65, and the standard error of the estimate was approximately 3.7\%. An analysis of residual dispersion (Figure 8(a)) shows that the model tends to overestimate the observed data, with higher amounts of positive than negative residuals. Those strata with a higher gap fraction (log decks and primary roads) accounted for most of the variation of residuals in the multiple regression analysis (Figure 8(b)).

To estimate forest cover, the model only accounted for those factors related to forest management. However, natural factors may also affect gap fraction in the canopy, including natural gaps and different forest types. Therefore, these other factors may account for the variation not explained by the model.

\section{Conclusions and Final Remarks}

This study investigated quantitative gap fraction estimates retrieved using different methods in selectively logged forests environments and their contribution to forest cover. The results indicate that there is a gradual increase in gap fraction relative to undisturbed forests, in the following order: skid trail, secondary roads, tree fall gaps, primary roads and log decks.

Additional studies should be conducted to aid the understanding of results obtained from these collection methods. Differences in instrument footprint, zenith angle spatial resolution (coarser for LAI-2000 than hemispherical imagery), and azimuthal range lead to the varied spatial sampling of transmittance by each instrument, which results in different estimates of gap fraction values over heterogeneous canopies. In this study, data produced with hemispherical photography were statistically more consistent, although processing has taken longer.

The understanding of canopy damage caused by forest management is also important for the interpretation

Table 4. Statistics for the adjusted model.

\begin{tabular}{cccc}
\hline $\mathbf{R}^{2}$ & Syx & Syx (\%) & $\boldsymbol{r}$ \\
\hline 0.65 & 3.19 & 3.77 & 0.80 \\
\hline
\end{tabular}

$\overline{\mathrm{R}^{2}}=$ adjusted coefficient of determination; Syx = standard error of the estimation, in the variable unit and in percentage; $r=$ correlation between estimated and observed values.

Table 5. Forest canopy losses estimated from hemispherical photos using a multiple regression model.

\begin{tabular}{|c|c|c|c|c|}
\hline & Estimate & Std. error & $t$ value & p-value \\
\hline Intercept & 89.486 & 0.36 & 248.78 & 0.000 \\
\hline Log decks & -13.955 & 0.512 & -27.256 & 0.000 \\
\hline Primary roads & -10.762 & 0.565 & -19.064 & 0.000 \\
\hline Secondary roads & -3.403 & 0.416 & -8.18 & 0.000 \\
\hline Tree fall gaps & -3.784 & 0.486 & -7.791 & 0.000 \\
\hline Skid trails & -1.481 & 0.547 & -2.705 & 0.007 \\
\hline
\end{tabular}




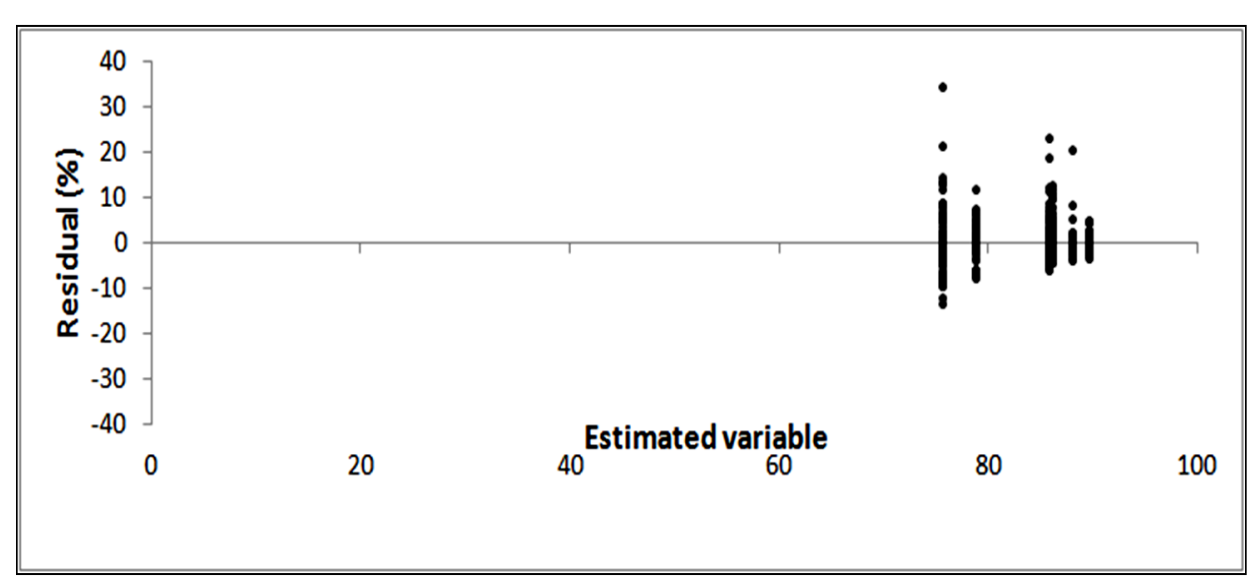

(a)

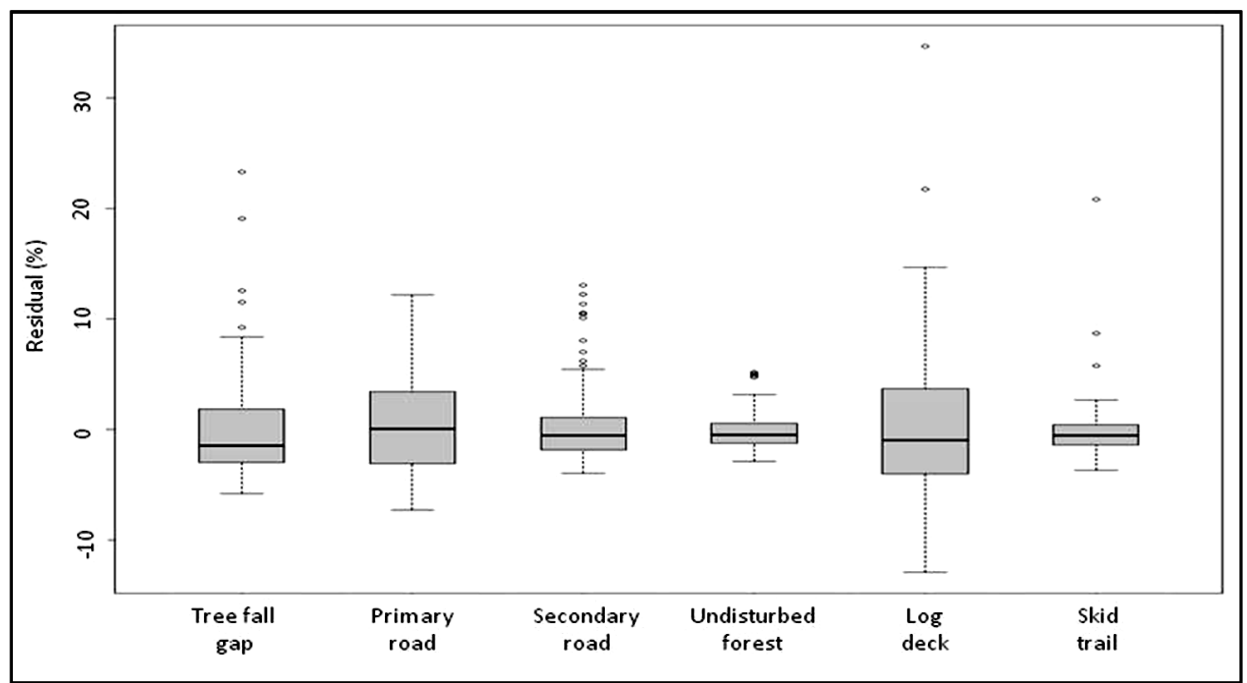

(b)

Figure 8. Residual dispersion of the adjusted model for estimating the contribution of forest cover (a) and a box plot graphic of the residual dispersion of each strata (b).

and detection of selective logging using remote sensing products [21], especially in the Amazon region, which covers extensive, remote and often inaccessible areas. This research was executed to support the validation of analysis conducted using remotely sensed data at JNF.

The approach proposed in this study is useful for the performance evaluation of the sustainable forest management plans, while also providing a quantitative track of logging impacts on the vegetation canopy in forest concession sites. Monitoring sustainable logging is crucial for ensuring the success of this activity, which will ultimately add efforts to mitigate climate change by improving the role of conservation, sustainable management of forests and enhancement of forest carbon stocks in REDD+ programs.

\section{References}

[1] Johns, J., Barreto, P. and Uhl, C. (1996) Logging Damage during Planned and Unplanned Logging Operations in the Eastern Amazon. Forest Ecology and Management, 89, 59-77. http://dx.doi.org/10.1016/S0378-1127(96)03869-8

[2] Barreto, P., Amaral, P., Vidal, E. and Uhl, C. (1998) Custos e Benefícios do Manejo Florestal para a Produção de Madeira na Amazônia Oriental. Vol. 10, Série Amazônia, Imazon, Belém.

[3] Welles, J.M. and Norman, J.M. (1991) Instrument for Indirect Measurement of Canopy Architecture. Agronomy Journal, 83, 818-825. http://dx.doi.org/10.2134/agronj1991.00021962008300050009x

[4] Pereira Jr., R., Zweede, J., Asner, G.P. and Keller, M. (2002) Forest Canopy Damage and Recovery in Reduced-Impact 
and Conventional Selective Logging in Eastern Para, Brazil. Forest Ecology and Management, 168, 77-89. http://dx.doi.org/10.1016/S0378-1127(01)00732-0

[5] Wu, L., Liu, J., Takashima, A., Ishigaki, K. and Watanabe, S. (2013) Effect of Selective Logging on Stand Structure and Tree Species Diversity in a Subtropical Evergreen Broad-Leaved Forest. Annals of Forest Science, 70, 535-543. http://dx.doi.org/10.1007/s13595-013-0292-x

[6] Sebben, A.M., Degen, B., Azevedo, V.C.R., Silva, M.B., Lacerda, A.E.B., Ciampi, A.Y., Kanashiro, M., Carneiro, F.S., Thompsom, I. and Loveless, M.D. (2008) Modelling the Long-Term Impacts of Seletive Logging on Genetic Diversity and Demographic Structure of Four Tropical Tree Species in the Amazon Forest. Forest Ecology and Management, 254, 335-349. http://dx.doi.org/10.1016/j.foreco.2007.08.009

[7] Thiollay, J.M. (1992) Influence of Selective Logging on Bird Species Diversity of a Guianan Rain Forest. Conservation Biology, 6, 47-63. http://dx.doi.org/10.1046/j.1523-1739.1992.610047.x

[8] Nepstad, D.C., Veríssimo, A., Alencar, A., Nobre, C., Lima, E., Lefebvre, P., Schlesinger, P., Potter, C., Moutinho, P., Mendoza, E., Cochrane, M. and Brooks, V. (1999) Large-Scale Impoverishment of Amazonian Forests by Logging and Fire. Nature, 398, 505-508. http://dx.doi.org/10.1038/19066

[9] Cochrane, M.A., Alencar, A., Schulze, M.D., Souza Jr., C.M., Nepstad, D.C., Lefebvre, P. and Davidson, E.A. (1999) Positive Feedbacks in the Fire Dynamic of Closed Canopy Tropical Forests. Science, 284, 1832-1835. http://dx.doi.org/10.1126/science.284.5421.1832

[10] Jonckheere, I., Fleck, S., Nackaerts, K., Muys, B., Coppin, P., Weiss, M. and Baret, F. (2004) Review of Methods for in Situ Leaf Area Index Determination Part I. Theories, Sensors and Hemispherical Photography. Agricultural and Forest Meteorology, 121, 19-35. http://dx.doi.org/10.1016/j.agrformet.2003.08.027

[11] Weiss, M., Baret, F., Smith, G.J., Jonckheere, I. and Coppin, P. (2004) Review of Methods for in Situ Leaf Area Index (LAI) Determination: Part II. Estimation of LAI, Errors and Sampling. Agricultural and Forest Meteorology, 121, 37-53. http://dx.doi.org/10.1016/j.agrformet.2003.08.001

[12] Gower, S.T., Kucharik, C.J. and Norman, J.M. (1999) Direct and Indirect Estimation of Leaf Area Index, fAPAR, and Net Primary Production of Terrestrial Ecosystems. Remote Sensing of Environment, 70, 29-51. http://dx.doi.org/10.1016/S0034-4257(99)00056-5

[13] Leblanc, S.G., Chen, J., Fernandes, R., Deering, D.W. and Conley, A. (2005) Methodology Comparison for Canopy Structure Parameter Extraction from Digital Hemispherical Photography in Boreal Forests. Agricultural and Forest Meteorology, 129, 187-207. http://dx.doi.org/10.1016/j.agrformet.2004.09.006

[14] Martens, S.N., Ustin, S.L. and Rousseau, R.A. (1993) Estimation of Tree Canopy Leaf-Area Index by Gap Fraction Analysis. Forest Ecology and Management, 61, 91-108. http://dx.doi.org/10.1016/0378-1127(93)90192-P

[15] Planchais, I. and Pontailler, J.-Y. (1999) Validity of Leaf Areas and Angles Estimated in a Beech Forest from Analysis of Gap Frequencies, Using Hemispherical Photographs and a Plant Canopy Analyser. Annals of Forest Science, 56, 1-10. http://dx.doi.org/10.1051/forest:19990101

[16] Hyer, E.J. and Goetz, S.J. (2004) Comparison and Sensitivity Analysis of Instruments and Radiometric Methods for LAI Estimation: Assessments from a Boreal Forests Site. Agricultural and Forest Meteorology, 122, 157-174. http://dx.doi.org/10.1016/j.agrformet.2003.09.013

[17] Garrigues, S., Shabanov, N.V., Swanson, K., Morisette, J.T., Myneni, R.B. and Baret, F. (2008) Intercomparison and Sensitivity Analysis of Leaf Area Index Retrievals from LAI-2000, AccuPAR, and Digital Hemispherical Photography Over Croplands. Agricultural and Forest Meteorology, 148, 1193-1209. http://dx.doi.org/10.1016/j.agrformet.2008.02.014

[18] Rich, P.M. (1990) Characterizing Plant Canopies with Hemispherical Photographs. Remote Sensing Reviews, 5, $13-29$. http://dx.doi.org/10.1080/02757259009532119

[19] Brasil (2000) Lei № 9.985, de 18 de julho de 2000. Instittui o Sistema Nacional de Unidades de Conservação da Natureza e dá outras providências. Diário Oficial da União, 18 de julho de 2000. http://www.planalto.gov.br/ccivil 03/leis/19985.htm

[20] ICMBio (2005) Plano de Manejo da Floresta Nacional do Jamari. Volume I, Diagnóstico, Brasília.

[21] Asner, G.P., Keller, M., Pereira Jr., R., Zweede, J.C. and Silva, J.N.M. (2004) Canopy Damage and Recovery after Selective Logging in Amazonia: Field and Satellite Studies. Ecological Applications, 14, 280-298. http://dx.doi.org/10.1890/01-6019

[22] Matricardi, E.A.T., Skole, D.L., Cochrane, M.A., Pedlowski, M. and Chomentowski, W. (2010) Assessment of Tropical Forest Degradation by Selective Logging and Fire Using Landsat Imagery. Remote Sensing of the Environment, 114, 1117-1129. http://dx.doi.org/10.1016/j.rse.2010.01.001

[23] LI-COR (2011) LAI-2200 Brochure. http://www.licor.com/env/pdf/area_meters/LAI-2200_brochure.pdf

[24] Frazer, G., Canham, C. and Lertzman, K. (1999) Gap Light Analyzer (GLA): Imaging Software to Extract Canopy 
Structure and Gap Light Transmission Indices for True-Color Fisheye Photographs, Users Manual and Program Documentation, Version 2.0. Simon Fraser University, Burnaby and The Institute of Ecosystem Studies, New York.

[25] Matricardi, E.A.T., Skole, D.L., Pedlowski, M.A. and Chomentowski, W. (2013) Assessment of Forest Disturbances by Selective Logging and Forest Fires in the Brazilian Amazon Using Landsat Data. International Journal of Remote Sensing, 34, 1057-1086. http://dx.doi.org/10.1080/01431161.2012.717182 
Scientific Research Publishing (SCIRP) is one of the largest Open Access journal publishers. It is currently publishing more than 200 open access, online, peer-reviewed journals covering a wide range of academic disciplines. SCIRP serves the worldwide academic communities and contributes to the progress and application of science with its publication.

Other selected journals from SCIRP are listed as below. Submit your manuscript to us via either submit@scirp.org or Online Submission Portal.
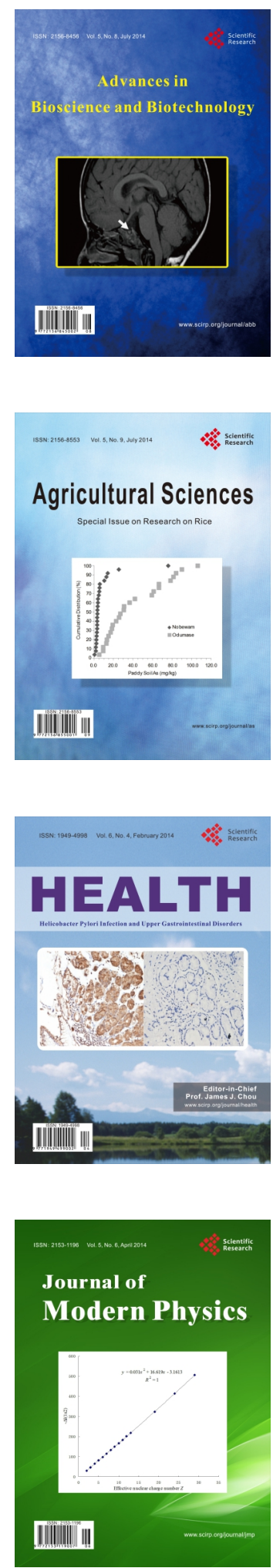
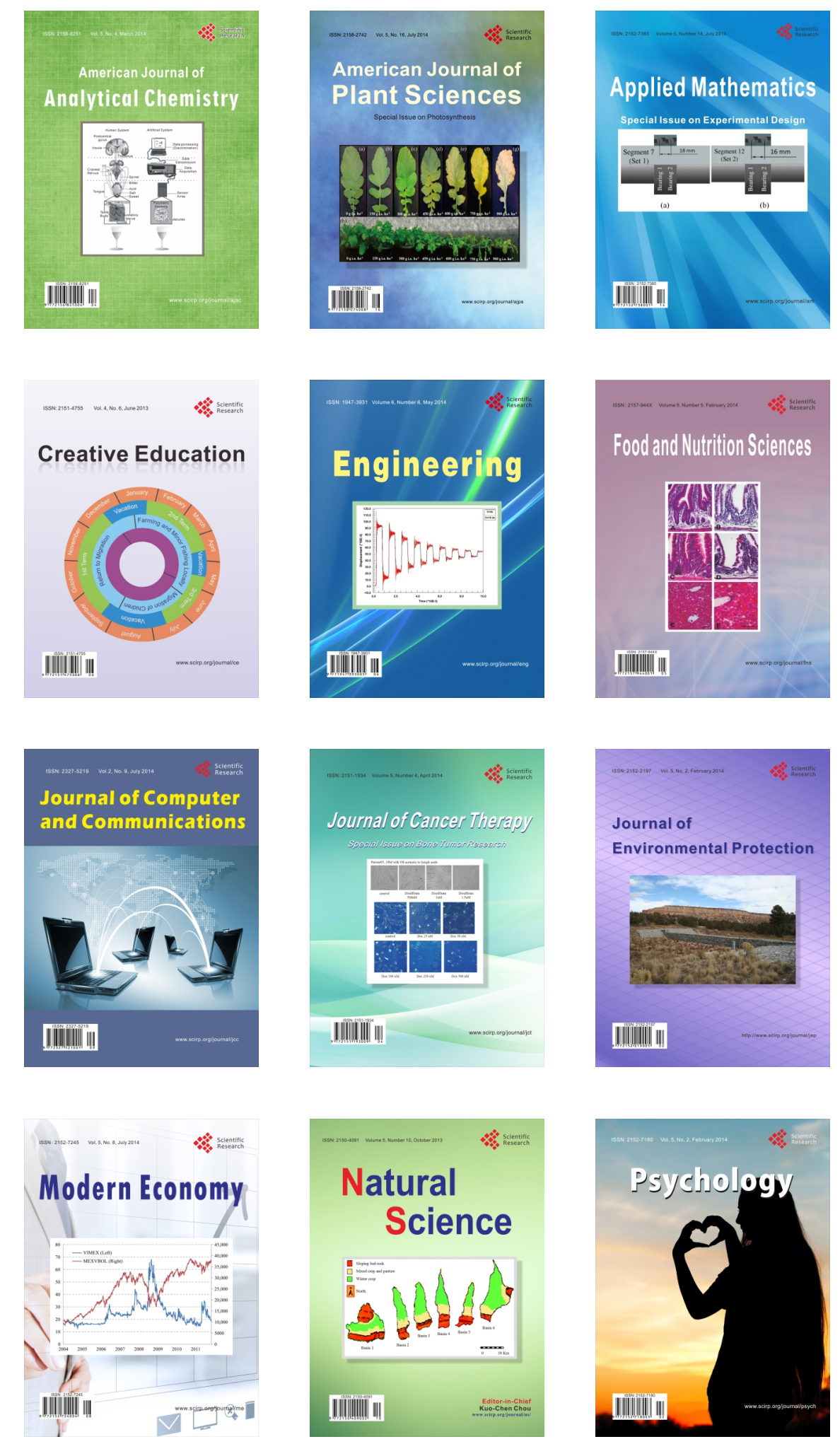